\title{
臨床研究中核病院と岡山大学
}

\author{
槇野博史
}

岡山大学理事 (病院担当), 岡山大学病院長

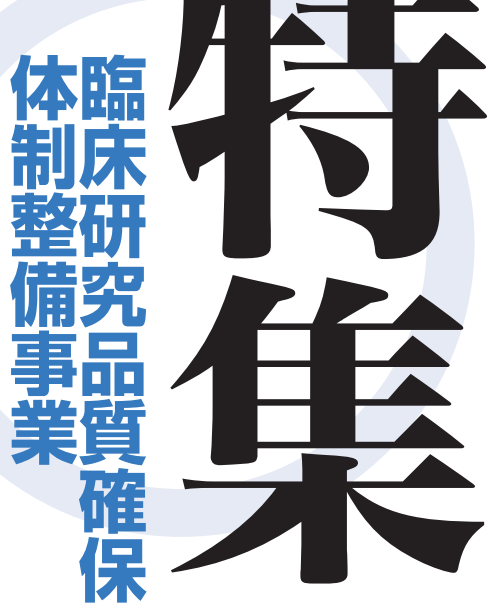

\section{Clinical Research Core Center and Okayama University}

Hirofumi Makino

Okayama University Executive Director (University Hospital), Okayama University Hospital Director

\section{はじめに}

岡山大学医学部は岡山藩医学館として147年前の明 治 3 年に創設され, 全国に80校ある国・公・私立の医 学部, 医科大学の中で屈指の古い歴史を有しています. 我が国ではこれまでの船団護衛方式に変わり，選択と 集中の時代に突入しています。この時代に生き残るた めにはその強みを生かしていく必要があります。岡山 大学病院の最大の財産は関連病院です。関連病院の数 は250と国内屈指の数です。数のみでなく質も高く, 200床以上の病院は83病院でそのベッド数の総数は 3.3 万床に達します。

そこで私は，まず新医療研究開発センター（病院長 がセンター長) が運営主体となって臨床研究の受け血 を整備しました。次に中国四国地方を軸として200床以 上の病院を中心に中央西日本臨床研究コンソーシアム を構築し, メガホスピタル化しました。岡山大学病院 の新医療研究開発センターを核に病院はもとより, 医 歯薬学総合研究科をはじめオール岡山大学の体制を構 築することができ, 平成 25 年に全国で10施設, 中国四 国地方で唯一の施設として臨床研究中核病院に選定さ れました。平成27年度からは，臨床研究品質確保体制 整備事業対象病院に名称変更しています。

翌年の平成 26 年には「健康寿命の延伸を目指した次 世代医療橋渡し研究支援拠点」の形成をテーマに医歯 薬学総合研究科と岡山大学病院のみならずオール岡山 大学の体制が機能して, 橋渡し研究加速ネットワーク プログラム事業に採択されました。臨床研究中核病院

平成28年12月27日受理

テ700-8558 岡山市北区鹿田町 2-5-1

電話：086-235-7500 FAX : 086-235-7636

E-mail :makino@md.okayama-u.ac.jp
と橋渡し研究加速ネットワークプログラム事業の両方 に採択され革新的医療技術創出拠点*として事業を展 開しているのは旧帝国大学，慶応義塾大学と岡山大学 だけです。

このような取組を踏まえ，更なる本国の臨床研究の 発展に寄与すべく, 本年度, 医療法上の臨床研究中核 病院の承認を目指し厚生労働省へ承認申請を行ったと ころであります (図 1 ).

本稿では, これらの取組み状況と, 岡山大学病院の 今後の展望についてご紹介します。

\section{平成25年度 : 臨床研究中核病院整備事業の承認}

日本国内で行われているアカデミア主導の臨床研究 の多くは，十分な研究体制が整っておらず，デー夕の 信頼性の担保ができていなかったり，計画段階で臨床 研究や生物統計に精通する専門家の関与が少なく，質 的な担保が行われていなかったり, GCP **等の臨床試 験関連規制に準拠する形での研究実施が人的・経済的 なリソースの問題で現実的でなかったり，それぞれ大 きな問題を抱えています。

これらを克服すべく，高精度の臨床研究実施あるい は支援の中核的役割を担う病院の整備を目的として， 臨床研究中核病院整備事業が平成24年に厚生労働省で 立案されました。これに対して計10医療機関が採択さ れ，本院も平成25年にその一機関として認められまし た ${ }^{1)}$. 本事業は計 5 年間（平成25年度〜平成29年度） であり，採択に際して当院は，(1)中国・四国地区の200 床以上の病院83施設を包含する国内最大級の臨床研究 コンソーシアム (中央西日本臨床研究コンソーシアム) の基盤強化 (メガホスピタル化)，(2)臨床研究支援人材 の育成拠点整備，(3)臨床研究を国際水準で実施する体 制整備，(4)産業化の促進・社会への還元という4つの 
課題を設けました（図 2 ).

平成25年以降現在までに, 当院新医療研究開発セン ター・研究推進課が中心となって, この 4 つの課題を 着実に実行しつつあります。例えば，本院を主幹施設 とする多施設共同の医師主導治験は現在 5 件走ってお り，それぞれ薬事承認（適応拡大）の可能性を常に意 識しつつ, 新医療研究開発センターに設置された $\mathrm{ARO}$ ***が研究の包括的支援にあたっています。また 中央西日本臨床研究コンソーシアム内の医療機関にお ける研究支援（プロトコル作成支援, 新医療研究開発 センターの医師・歯科医師によるモニタリング業務,
監査業務など）も多面的に展開しております。同時に 国立大学病院臨床研究推進会議 中国・四国地区連絡 会を定期開催し,各大学病院との密な情報交換を行い, コンソーシアム内での共同研究の促進にも努めていま す．教育に関しては，適正な研究を実施していくこと を目的に，研究者に対する定期的な講習会を精力的に 実施し，学部学生に対してもレギュラトリーサイエン ス****の講義を開始しました.また院内より PMDAへ の出向を通じて，薬事に関する視野視点を持った者の 養成・確保も行っています.

革新的医療技術創出拠点

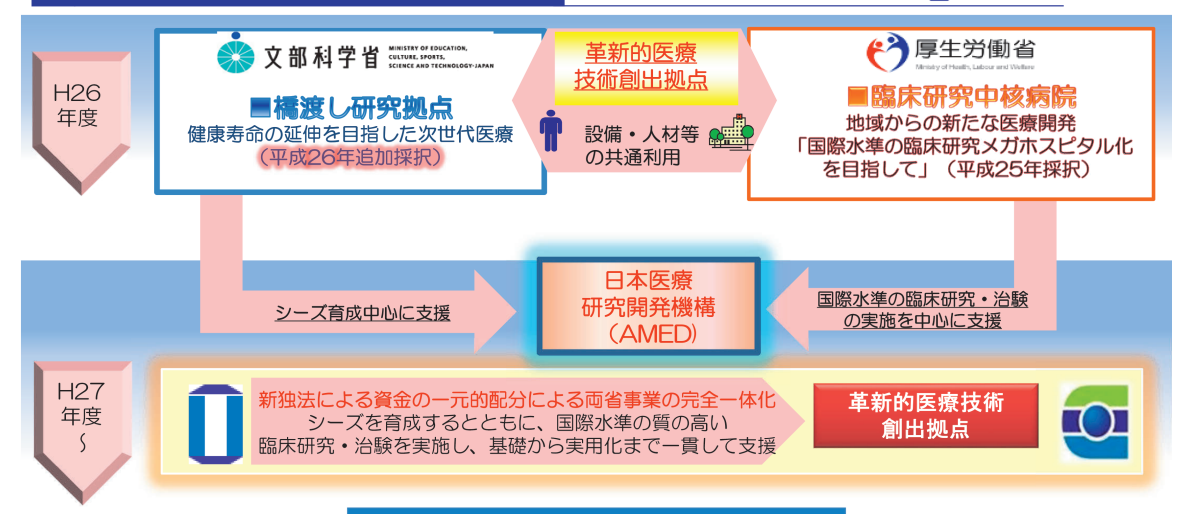

両事業の採択による体制整備

医療法上の臨床研究中核病院申請 (平成28年度) 日本の臨床研究が抱えるデータの信頼性及び試験デザインの質的担保の課題を解決しつつ、世界 に向けて日本発の製品開発を進める拠点として、臨床研究活動の一層の推進並びに体制整備と人 材育成を達成し、最終的には研究成果を社会に還元して国民の健康並びに福祉の向上に貢献する。

図 1 岡山大学病院の革新的医療技術創出拠点の採択状況

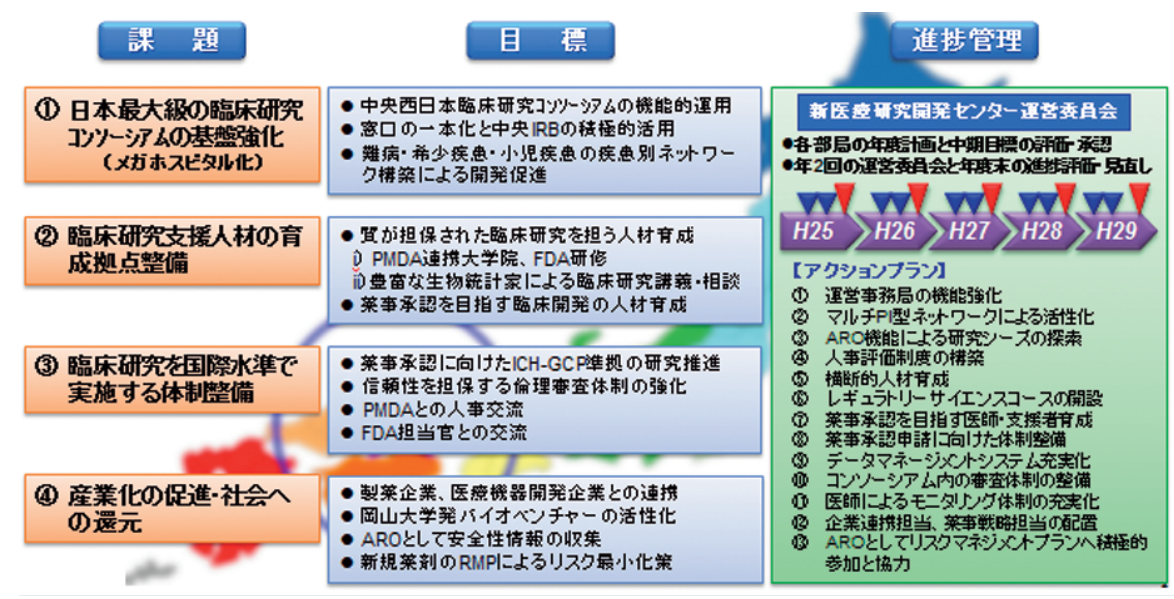

図 2 臨床研究中核病院としての岡山大学病院の取り組み（平成25年度当時） 


\section{平成26年度 : 橋渡し研究加速ネットワークプログラム 事業の承認}

\section{1. 橋渡し研究加速ネットワークプログラムの概要}

橋渡し研究加速ネットワークプログラムは, 文部科 学省が取りまとめる事業の一つです。本事業では, 画 期的な医薬品・医療機器等を効率的・効果的に国民へ 還元することを目指し, 大学等発の有望な基礎研究成 果の臨床研究・治験への橋渡しをさらに加速するた め, 全国 9 力所の橋渡し研究支援拠点（図 3 ) のシー ズ育成能力を強化するとともに, 恒久的な橋渡し研究 支援拠点を確立させることを目的としています2). 平 成16年の文部科学省事業「革新的ながん治療法等の開 発に向けた研究の推進一トランスレーショナル・リ サーチ事業の推進一」にはじまり, 平成19年の「橋渡 し研究支援推進プログラム」事業（第 1 期プログラム） を経て，本第 2 期プログラムへと事業が継承されまし た.このおよそ10年間に事業採択拠点での橋渡し研究 支援体制が整備され，各拠点での支援人材の定員化や， 外部収入を得て自立化を進める仕組みが整備されまし た。また, 本事業の重要な目的の一つに,「拠点間ネッ トワークの構築」が挙げられます。アカデミア間での 開発人材や設備リソースの共有, 相互モニタリング事 業など拠点間で臨床試験, 治験を効率的に行うための 取組も着実に進められてまいりました。

橋渡し研究（トランスレーショナルリサーチ）とい う, シーズの実用化において最も難しいとされる臨床 研究をアカデミアが実施することは, 新しい薬や医療
機器の開発を行う上で大変重要なミッションの一つで あり，まさに日本のアカデミアが総力を挙げて，互い に連携しながら取り組むべき課題であります。

2. 岡山大学における橋渡し研究加速ネットワークプ ログラム事業の承認と具体的な取組み

岡山大学は平成 26 年度の橋渡し加速ネットワークプ ログラム拠点に採択されました。

岡山大学は本事業において「健康寿命の延伸を目指 した次世代医療橋渡し研究支援拠点」の形成を揭げて おり，これまで高齢化による新たな医療分野での研究 開発を視野に見据え, 多様な医療ニーズに対応すべく 橋渡し研究拠点を形成することを目的として，特色あ る事業展開を行っております。

岡山大学が掲げる「健康寿命の延伸」に資する領域 とは, 従来の疾患の診断・治療にとどまらず，適切な 診断と対策による疾患発症予防，並びに治療に伴う合 併症や疾患の重症化を防ぐ取り組みを指しています。 これは医科・歯科領域の医療だけでなく, 看護, 介護, 福祉, さらには公衆衛生など多方面にわたる領域です. また岡山大学は先に述べた通り, 現在中国四国地方の 医療機関・研究者ネットワークである「中央西日本臨 床研究コンソーシアム」を形成しており, 多彩な疾患 領域において臨床研究, 疫学研究を実施する基盤を有 しています。さらに中国四国地方の医科系・歯科系大 学とも研究や診療において相互に協働することが可能 な立場にあります。このような医療機関, 研究者ネッ トワークに加え, 大学病院ネットワークを背景に, 中 国四国地方での「健康寿命の延伸」に寄与するシーズ

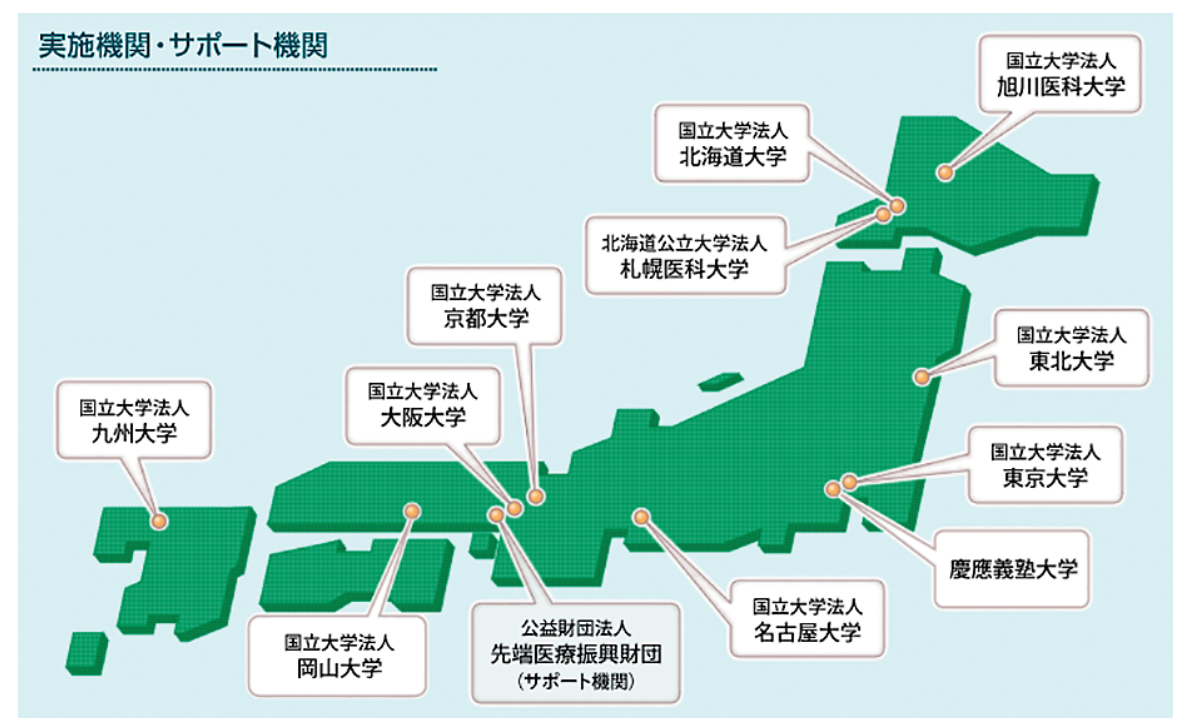

図 3 橋渡し研究加速ネットワークプログラム採択拠点及び拠点サポート機関 
の掘り起こし並びに育成を進めるべく，本事業におい て積極的な拠点形成を行ってまいりました，特にシー ズの評価・選考に関しては, 橋渡し研究加速ネットワ ークプログラム採択以前より，医療分野に高い専門性 と実務経験を有する URA を基軸にオール岡山大学の 体制が構築されており, さらに岡山大学研究推進産学 官連携機構における医療系本部の新規設置, 並びに新 医療研究開発センターにおける橋渡し支援機能を強化 することで, 岡山大学拠点が中国四国地区シーズ育成 の中心的役割を担うことを目指してまいりました.

橋渡し研究加速ネットワークプログラム採択後の 2 年余りの間に, 小览心不全に対する心筋幹細胞再生医 療 (新医療研究開発センター王英正教授), 岡山大学 方式人工網膜 (眼科 松尾俊彦准教授, 自然科学研究 科 内田哲也准教授), 肺サーファクタントをアジュバ ントとする経鼻インフルエンザワクチン（徳島大学先 端酵素学研究所 木戸博教授) といった, 中四国を代表 する革新的シーズが橋渡し研究加速ネットワークプロ グラムのシーズC（治験又は高度・先進医療等を実施 し，ヒト proof of concept（POC）取得を目指す課題） に採択されています。また岡山大学のシーズ管理状況 として, 平成28年現在, 医歯薬学領域で合計83件のシ ーズを開発パイプラインとして登録し, 各々のシーズ においてプロジェクトマネージャが開発の進捗を管理 する体制となっています。

本事業で掲げる健康寿命の延伸を目指した医療を実 現するためには, 関連病院並びに中国四国地方の各大 学の協力なくしては成り立ちません. 今後はさらに拠
点のシーズ育成機能の強化と, 拠点間連携, 中四国大 学間連携をさらに強固なものにしてまいります。

\section{平成28年度 : 医療法上の臨床研究中核病院申請}

臨床研究に関して世間で非常に厳しい目が注がれて いる状況下でも, 医療の発展のために臨床研究を進め ていくニーズは明確です。したがって，主導的に臨床 研究を推進・支援する役割を担う臨床研究中核病院の 存在は極めて重要であり, 法制化の上, 認定・整備さ れるべきだという当局をはじめ有識者の間で議論が以 前よりありました。

様々な討議の末, 平成 27 年 4 月から, 臨床研究中核 病院は医療法上に位置付けられ, 従来（平成24, 25年 度認定) の臨床研究中核病院 (以後, 臨床研究品質確 保体制整備事業対象病院へ名称变更；図 4) とは別途 にさらにレベルの高い認定要件が設定されました3). 既に旧帝国大学を中心とした施設が新規に認定を受け ています（表 1 ).

本院においても,「医療法上の臨床研究中核病院」の 承認を目指します.その公的交付金を獲得 - 活用の上,

(1)岡山大学が, 臨床研究実施・支援の中四国におけ る拠点として，その実装を目指す

(2)院内各診療科等の研究者が, 国際水準の研究を適 正かつ快適に進められるよう，院内支援体制をさ らに整える

(3)院内の臨床研究者に対する教育の体制を整備する をそれぞれ実現し, 岡山大学病院における臨床研究力 の更なる底上げに繋げたく思います。

\section{平成}

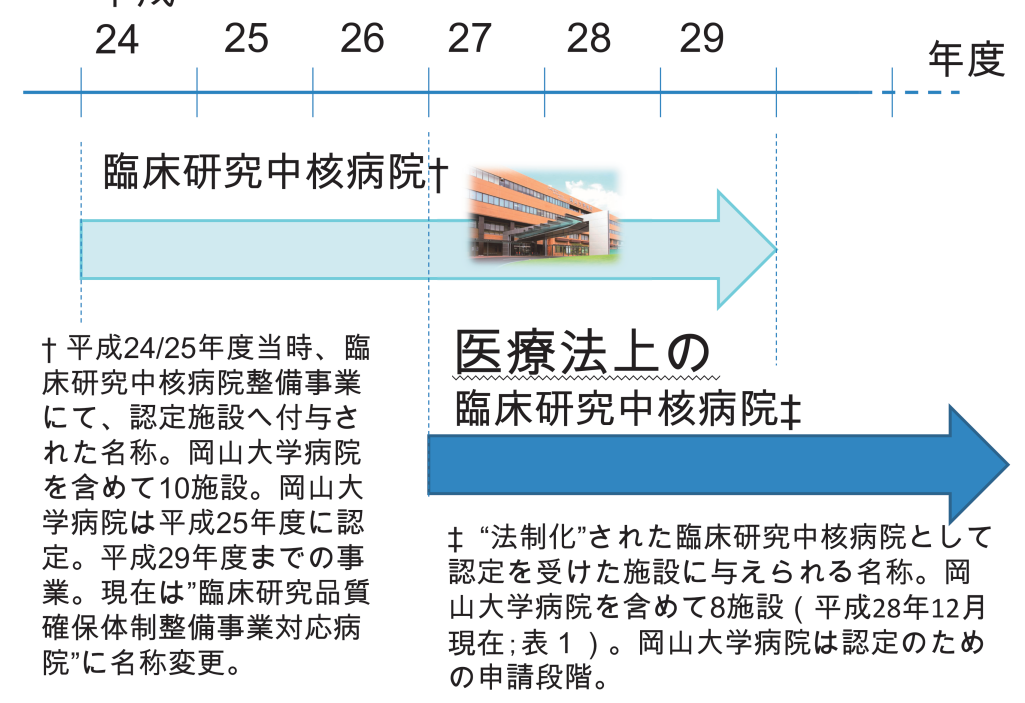

図 4 臨床研究品質確保整備事業病院（旧：臨床研究中核病院）と医療法上の臨床研究中核病院 
表 1 医療法に基づく臨床研究中核病院（平成28年12月現在）

\begin{tabular}{|c|c|c|c|}
\hline 名称 & 所在地 & 承認年月日 & 承認の効力発生年月日 \\
\hline 国立がん研究ゼノ夕ー中央病院 & 東京都中央区築地5-1-1 & 平成27年8月7日 & 平成27年8月7日 \\
\hline 東北大学病院 & 宮城県仙台市青葉区星陵町1-1 & 平成27年8月7日 & 平成27年8月7日 \\
\hline 太阪大学医学部附属病院 & 大阪府吹田市山田丘2番15号 & 平成27年8月7日 & 平成27年8月7日 \\
\hline 国立がん研究ゼノター東病院 & 千杗県柏市柏の杗6-5-1 & 平成27年9月29日 & 平成27年9月29日 \\
\hline 名古屋大学医学部附属病院 & 愛知県名古屋市昭和区鶴舞町65番地 & 平成28年1月27日 & 平成28年1月27日 \\
\hline 九州大学病院 & 福岡県福岡市東区馬出三丁目1番1号 & 平成28年1月27日 & 平成28年1月27日 \\
\hline 東京大学医学部附属病院 & 東京都文京区本郷7 -3-1 & 平成28年3月25日 & 平成28年3月25日 \\
\hline 酋應義勍大学病院 & 東京都新宿区信濃町35番地 & 平成28年3月25日 & 平成28年3月25日 \\
\hline
\end{tabular}

院内各診療科等の諸先生方にはご多忙のところご協 力をいただき感謝申し上げます。認定に向けて目下， 院内での各種準備を鋭意行っているところであり, 是 非とも関連各位におかれましては，引き続きのご理解 やご支援をいただけますと幸いです。

\section{今後の将来展望}

岡山大学病院の臨床研究の特色はバイオバンクを同 時に立ち上げていることです。バイオバンクは病気の 予防・治療・創薬にわたる医学研究を支える資源を提 供しており，この基盤整備により今後の発展が期待で きます。バイオバンク事業は，産学官金の良いモデル です，創薬をめざして産業界と共同研究を進め, 日本 医療研究開発機構 $(A M E D) \cdot$ 文部科学省などに施策 を提言して，金融機関との提携を含好研究と実践人 を育成しながら創薬に結び付け, その結果として経営 基盤を確立することができます。

現在, 米国カリフォルニア州フリーモント市（サン フランシスコ・ベイエリア）に岡山大学のサテライト オフィスがあり, 国際拠点となっています。世界の大 学・企業と連携して創薬と医療機器開発のグローバル な展開が期待できます。

私はこの 4 月より次期学長を帱命しており,「しなや かに超えて行く実りの学都へ」を揭げ，「課題にみちた 今の社会に, 新しいアイデアの科学的創造と実践的な 人づくりで貢献していく岡山大学」を目指しておりま す. 岡山大学病院には医療法上の臨床研究中核病院と しての成果を充分に挙げて, 岡山大学の発展を牽引し て頂けたらと期待します。

\section{謝辞}

本稿執筆にご協力を頂いた新医療研究開発センターの堀田勝 幸教授，櫻井淳講師に深謝いたします.

\section{文献}

1 ) 那須保友 : 特集 臨床研究中核病院から臨床研究中核病院 「岡山大学病院」. 岡山医会誌（2014）126, 231-235.

2 ) 文部科学省：橋渡し研究加速ネットワークプログラム。 http://www.tr.mext.go.jp/outline.html (平成28年12月閲覧)

3 ) 那須保友: 特集 臨床研究品質確保体制整備事業 総合診療 棟 (II 期) 新営工事に伴う臨床研究中核病院（医療法上） に向けた整備について，岡山医会誌（2016）128，217-220.

\section{用語解説}

*革新的医療技術創出拠点

文部科学省の推進事業であった橋渡し研究加速ネットワークプ ログラム事業と, 厚生労働省の推進事業であった臨床研究中核 病院関連の各種事業を一体化し, 日本医療研究開発機構が一元 化した事業実施体制の整備を進めている拠点

(日本医療研究開発機構 (AMED) のホームページ : http:// www.amed.go.jp/)

** GCP (Good Clinical Practice)

「薬事法」というくすり全般に関する法律とともに，治験を行 う製薬会社・病院・医師が守らなければならない，国が定めた 規制

この規則は欧米諸国をはじめ国際的に認められている. (厚生労 働省「治験」のホームページ：http://www.mhlw.go.jp/topics/ bukyoku/isei/chiken/01.html)

***ARO (Academic Research Organization) 大学等アカデミアによる医薬品/機器開発の支援グループ. 医 師を含む科学的・学問的側面に強い支援，あるいは PMDA（医 薬品医療機器総合機構）経験者を含む薬事・当局対策に強い支 援等，研究者に近い立ち位置からの研究支援を実施できる.

****レギュラトリーサイエンス

科学技術の成果を人と社会に役立てることを目的に，根拠に基 づく的確な予測, 評価, 判断を行い, 科学技術の成果を人と社 会との調和の上で最も望ましい姿に調整するための科学 (独立行政法人医薬品医療機器総合機構ホームページ : https:// www.pmda.go.jp/rs-std-jp/outline/0001.html) 